\title{
Technological Pedagogical Content Knowledge: Ability Prospective Teachers Biology Education Department In Jakarta Indonesia
}

\begin{abstract}
Irdalisa $^{1}$, Tuti Marjan Fuadi², Mega Elvianasti ${ }^{3}$, Bagus Endri Yanto ${ }^{4}$
Article History:

Received 22.03.2021

Received in revised form

28.12.2021

Accepted

Available online

01.03.2022

The era of globalization and pandemic has greatly affected education, especially in the teaching and learning processes. Offline learning system must be changed to an online learning system. Prospective teachers are required to explore both knowledge and technology, so that effective and meaningful learning can be created. This research was a descriptive study with a quantitative approach to determine, analyze, and describe the Technological Pedagogical Content Knowledge (TPCK) abilities of prospective teachers of the Biology Education Department A private university in Jakarta, Indonesia. The research subjects were 8th semester students totaling 197 students. The instrument for collecting data on the TPACK ability of prospective teachers was questionnaires distributed through Google Forms. The results of questionnaire analyzed seven aspects of the TPACK abilities of prospective Biology teachers, including Technological Knowledge (TK), Content Knowledge (CK), Pedagogical Knowledge (PK), Pedagogical Content Knowledge (PCK), Technological Content Knowledge (TCK), Technological Pedagogical Knowledge (TPK), and Technological Pedagogical and Content Knowledge (TPCK). The results of this study indicated that the TPCK ability of prospective teachers is in sufficient criteria with an average value of 3.15. This showcases that it is still necessary to improve the TPACK abilities of prospective teachers in several aspects, namely mastery of content, pedagogy, and technology. ICT-based educational innovation is also needed to develop learning tools and instruments based on TPCK for prospective teachers of Biology Education Department A private university in Jakarta, Indonesia.
\end{abstract}

(C) IJERE. All rights reserved

Keywords: Prospective teacher of biology, content, pedagogy, and technology

\section{INTRODUCTION}

The integration of technology in teaching and learning activities is an important aspect in achieving teaching success. Rahmadi, (2015) stated that the era of the industrial revolution 4.0 and the COVID-19 pandemic that hit Indonesia demand changes and improvements in mastery of technology in all fields, especially the field of education. The use of technology in the learning process has become a major concern for all components of education because it is considered an important factor to improve the quality of education (Jimayonis, 2010). The purpose of technology in education is to increase technological literacy among students, improving the quality of learning, and encouraging problem solving activities (Meenakshi, 2013).

Teachers need to understand how ICT and pedagogy are interrelated to facilitate the development of 21st century competencies in their students (Voogt et al., 2013). Technological Pedagogical Content Knowledge (TPCK) is an integration between ICT, pedagogy, and content that is applied according to the context of the learning process (Koehler \& Mishra, 2009). Teachers are required to master TPACK to ensure that they can easily create their own media, materials, and learning tools with the latest technology (Irdalisa, et al., 2020). According to Paidi et al., (2021), TPACK is important for teachers because it affects the way they deliver learning materials. Mastery of TPACK in the learning process can improve students' achievement. The results of the research by Irmita and Atun (2018) state that the application of the TPACK in learning has a significant effect on students' scientific literacy and social skills.

Biology learning materials are not only related to scientific facts about concrete natural phenomena, but also abstract things or objects. The use of technology can affect students' learning experiences, as well as improving educational products and processes (Bhakta \& Dutta, 2016; Kriek \& Coetzee, 2016). Teachers must use appropriate technology (learning media) to support the biology learning process (Paidi et al., 2021). The use of technology in learning will enable students to understand abstract biological material. The use of ICT in learning will also help students understand concepts easily (Raja \& Nagasubramani, 2018). In addition, in learning biology, practical activities can support students' understanding of the material. Practical activities can form illustrations of biological concepts. The current pandemic is a problem for teachers because

\footnotetext{
${ }^{1}$ Muhammadiyah University of Prof. Dr. Hamka, irdalisa@uhamka.ac.id, orcid.org/0000-0003-2523-6039

2 University Abulyatama, tuti.marjan@yahoo.com, orcid.org/0000-0001-8970-7560

${ }^{3}$ Muhammadiyah University of Prof. Dr. Hamka, megaelvianasti@uhamka.ac.id, orcid.org/0000-00002-3530-4587

${ }^{4}$ State Islamic Institute of Bengkulu, bagus@iainbengkulu.ac.id, orcid.org/0000-0003-4009-9482
} 
practical activities are difficult to carry out. With the use of ICT, the comprehensiveness of teaching becomes a reality.

The existence of learning tools is needed to make it easier for teachers to carry out the learning process. However, learning tools are still limited and simple (Sani, 2013). The development of learning tools and instruments in schools has not been ensured optimally because many teachers have limited understanding and tend to use traditional methods. Prospective teachers who will later teach in schools are expected to understand and be able to design learning tools and instruments based on ICT so that they can make high quality and meaningful learning. To improve the quality of education, especially the quality of biology learning in schools, not only teachers must be professionally developed, but also the quality of their preparation must be improved. Mario et al., (2016) say that updating science and technology requires a teacher as an educator to be ready, alert, and continue to develop his or her knowledge to face changes in order to become a productive and professional teacher. The teachers' role as a facilitator must be able to package learning activities to be effective, efficient, scientific, and fun. This is in accordance with the goals of national education, namely the achievement of the role of professional educators (Sani, 2013). According to Elvianasti et al., (2019), professional teachers have four competencies, namely pedagogic competence, personal competence, social competence, and professional competence. According Mulyasa (2009), states that the pedagogical competence is the ability of teachers in the management of education of students. Teacher's personal competencies include knowledge of the subject matter, effective communication skills, punctuality, being a disciplinarian and understanding the nature of child psychology. The personal competence of teachers include knowledge of the subject matter, effective communication skills, punctual, disciplined and understand the character of psychology children. The professional competence of teachers is mastery over the subject matter is broad and deep. Social competence is the sum of knowledge and skills of a person that determines the quality of socially competent behaviour. These competencies are actualized in the form of behavior in daily activities, both in carrying out tasks in learning and in community activities.Many studies state that the TPACK framework helps teachers' self-efficacy in integrating technology in classroom learning effectively, as well as their professional development and teachers' competence in integrating technology. Therefore, it is necessary to analyze the TPACK mastery of prospective teachers of the Biology Education Department to provide an overview of their abilities of TK, CK, PK, PCK, TCK, TPK, and TPACK in order to improve the quality of learning. The results of this study can also provide consideration in determining policies related to curriculum development.

\section{RESEARCH DESIGN and METHOD}

\section{Research design}

This research is a descriptive study with a quantitative approach to determine, analyze, and describe the TPACK abilities of prospective teachers of the Biology Education Department, at A private university in Jakarta, Indonesia.The research subjects were 8th semester students who took PPL (Field Experience Practice) courses, totaling 197 people consists of 100 women, 97 men, aged between 19-20 years, Javanese. The instrument for collecting data on the TPACK ability of prospective teachers was open and closed questionnaires distributed through Google Forms.

Table 1: Open Questionnaires Distributed

\begin{tabular}{|c|c|}
\hline No. & Questions \\
\hline 1. & As a prospective teacher, how do you increase your knowledge of biology? \\
\hline 2. & If when teaching you know the possibility of misconceptions in students, how do you overcome them? \\
\hline 3. & How do you manage the class during the learning process \\
\hline 4. & How do you assess student performance in class? What technique do you use? \\
\hline 5. & In your opinion, is literacy skill important? Why is that? \\
\hline 6. & As a prospective teacher, how do you improve your IT literacy skills in science learning? \\
\hline 7. & Do you use internet facilities as a medium of communication? If so, what media do you use? \\
\hline 8. & Have you ever attended a seminar related to virtual laboratories? \\
\hline 9. & In your opinion, how important is the virtual laboratory in implementing practical activities today? \\
\hline 10. & In your opinion, how important is the virtual laboratory in implementing practical activities today? \\
\hline 11. & Can you design a biology experiment for learning purposes? What experiments are you designing? \\
\hline 12. & Do you have knowledge in developing learning tools? What learning tools have you designed? \\
\hline 13. & What is your strategy if there are students who have difficulty understanding the material you teach? \\
\hline 14. & How do you as a prospective teacher make students technology literate? \\
\hline 15. & Have you integrated technology, content and learning strategies in the learning process so far? \\
\hline 16. & Have you ever given online tests to students to measure mastery of the material? If so, what application do you use? \\
\hline 17. & What do you do to facilitate students to use technology in finding information independently related to the material being studied? \\
\hline
\end{tabular}


Table 2: Closed Questionnaires Distributed

Questions

I am enthusiastic about keeping up with the latest technological developments.

I have the technical skills needed to use a computer effectively.

I am proficient in using information and communication technology in learning and for presentations.

I can use internet facilities as a medium of communication.

I master the biology material that I will teach to students

I use scientific thinking in the learning process.

I have various ways and strategies to increase students' understanding of the biology material that I teach.

I use the latest learning resources and references, both books and journals to increase my knowledge of biology.

I can design biology experiments for learning purposes.

I am enthusiastic to attend seminars related to virtual lab-based practicum.

0.

I know how to assess student performance in class.

1.

I am able to apply a variety of learning strategies to improve students' thinking and learning processes in biology.

I know about technology that can be used to understand and teach literacy.

3.

I know about technology that can be used to understand and teach biology.

4.

I am able to manage and control the class during the learning process

5.

I am able to use various assessment methods and techniques

6.

I know the possibility of misconceptions in students

7.

I can direct and guide students to discuss effectively during group work.

8.

I do reflection activities to improve the quality of learning in the classroom

I can adapt my teaching style based on the different abilities of students

I have knowledge in developing learning tools

I can design independent learning activities for students through the use of ICT.

2.

I can choose and use technology that is appropriate to the biology material to be taught.

3.

I use technology to help students understand biology material.

4.

I prepared my own learning scenario

5.

I can make lesson plans (RPP) with a good understanding of biology topics.

6.

I can choose approaches and learning strategies that are appropriate to the biology material to

7. be taught and the level of development of students.

I can make difficult biology material easy for students to understand.

I can develop learning evaluations to measure students' mastery of the biology material that I

9. teach.

I can facilitate students to use technology to find more information independently.

0.

I have the knowledge and ability to develop student activities and assignments that involve

1. the use of technology.

I can do tests to measure the mastery of the material online to students.

2 .

I am able to use learning media and learning resources that are relevant to the students and the subjects being taught.

I can adapt learning strategies and technology to the biology material that will be delivered in classroom learning activities.

I apply different learning strategies and use various computer applications in the

5. implementation of learning practices.

I can teach by integrating the right technology, content and learning strategies. 
The results of the distributed questionnaire analyzed seven aspects of the TPACK ability of prospective biology teachers, including Technological Knowledge (TK), Content Knowledge (CK), Pedagogical Knowledge (PK), Pedagogical Content Knowledge (PCK), Technological Content Knowledge (TCK), Technological Pedagogical Knowledge (TPK), and Technological Pedagogical and Content Knowledge (TPACK) in accordance with what has been developed by Mishra and Koehler (2006). The data obtained were then searched for the average (mean) using the Husein, (2011) formula, namely:

$$
\text { Mean }=\frac{\Sigma(\text { frequency } * \text { weight })}{\Sigma \text { Population }(n)}
$$

The average score obtained was then categorized to find out the TPACK ability of the prospective biology teachers. The criteria used were proposed by Husein (2011) which can be seen in Table 3 .

Table 3: Criteria for the Ability of Prospective Biology Teachers

\begin{tabular}{cc}
\hline Interval & Criteria \\
\hline $1.00-1.80$ & Very bad/very low \\
$1.81-2.60$ & Not good/low \\
$2.61-3.40$ & Enough/moderate \\
$3.41-4.20$ & Good/high \\
$4.21-5.00$ & Very good/very high \\
\hline
\end{tabular}

\section{RESULTS}

Based on the results of the questionnaire regarding the TPACK ability of prospective teachers of the Biology Education Department A private university in Jakarta, Indonesia shows that the average TPACK ability of prospective teachers is in sufficient criteria with an average value of 3.15 (Table 4).

Table 4: Results of TPACK Aspect Questionnaire Analysis

\begin{tabular}{clcc}
\hline No & \multicolumn{1}{c}{ TPACK Aspect } & Mean & Criteria \\
\hline $\mathbf{1}$ & Technological Knowledge (TK) & 3.41 & Good \\
$\mathbf{2}$ & Content Knowledge (CK) & 3.11 & Enough \\
$\mathbf{3}$ & Pedagogical Knowledge (PK) & 3.06 & Enough \\
$\mathbf{4}$ & Pedagogical Content Knowledge (PCK) & 3.09 & Enough \\
$\mathbf{5}$ & Technological Content Knowledge (TCK) & 3.13 & Enough \\
$\mathbf{6}$ & Technological Pedagogical Knowledge (TPK) & 3.14 & Enough \\
$\mathbf{7}$ & Technological Pedagogical and Content Knowledge (TPACK) & 3.10 & Enough \\
\hline
\end{tabular}

\section{Technological Knowledge (TK)}

TK is knowledge on how to use various technologies. The results of the questionnaire data analysis on TK can be seen in Table 5 .

Table 5: Result of Technological Knowledge (TK) Analysis.

\begin{tabular}{|c|c|c|c|}
\hline No & Statements & Mean & Criteria \\
\hline 1 & Enthusiastic to keep up with the latest technological developments. & 3.70 & Good \\
\hline 2 & Having the technical skills needed to use computers effectively. & 3.17 & Enough \\
\hline 3 & $\begin{array}{l}\text { Proficient in using information and communication technology in learning as } \\
\text { well as for presentations. }\end{array}$ & 3.17 & Enough \\
\hline 4 & Able to use the internet as a medium of communication. & 3.70 & Good \\
\hline 5 & $\begin{array}{l}\text { Enthusiastic to attend seminars related to virtual laboratorium-based } \\
\text { practicum. }\end{array}$ & 330 & Enough \\
\hline & Average & 3.41 & Good \\
\hline
\end{tabular}


The results of the analysis show that the ability of the prospective biology teacher's Technological Knowledge (TK) is in good criteria with an average value of 3.14. This shows that prospective teachers have sufficient knowledge of technology and are able to apply them in the learning process. If students as prospective teachers are enthusiastic about following the latest technological developments, it indicates that they already have the awareness to keep up with existing technological developments.

\section{Content Knowledge (CK)}

Content Knowledge (CK) is knowledge about materials/subjects that must be mastered when teaching (Kohler et al., 2014; Schmidt and Mishra, 2009). The results of the questionnaire data analysis on the CK aspect can be seen in Table 6 .

Table 6: Results of Content Knowledge (CK) Analysis

\begin{tabular}{|c|c|c|c|}
\hline No & Statements & Mean & Criteria \\
\hline 1 & Mastering the biology materials that I teach to students. & 3.13 & Enough \\
\hline 2 & Using scientific thinking in the learning process. & 3.10 & Enough \\
\hline 3 & $\begin{array}{l}\text { Having a variety of ways and strategies to improve students' understanding of the } \\
\text { Biology material that I teach. }\end{array}$ & 3.00 & Enough \\
\hline 4 & $\begin{array}{l}\text { Using the latest learning resources and references, both books and journals to } \\
\text { increase knowledge about biology. }\end{array}$ & 3.23 & Enough \\
\hline 5 & Able to design biological experiments for learning purposes. & 3.10 & Enough \\
\hline & Average & 3.11 & Enough \\
\hline
\end{tabular}

The results of the analysis show that the Content Knowledge (CK) ability of prospective biology teachers is in sufficient criteria with an average value of 3.11. In line with studies showing that teacher candidates are often lacking in conceptual understanding of the content to be taught.

\section{Pedagogical Knowledge (PK)}

Pedagogical Knowledge (PK) is knowledge of various teaching strategies and methods including knowledge of classroom management, assessment of learning, and development of lesson plans (Kohler et a.1, 2014; Schmidt and Mishra, 2009). The results of the questionnaire data analysis on the PK can be seen in Table 7.

\section{Table 7: Results of PK Aspect Analysis}

\begin{tabular}{|c|c|c|c|}
\hline No & Statements & Mean & Criteria \\
\hline 1 & Understand how to assess students' performance in class. & 3.07 & Enough \\
\hline 2 & $\begin{array}{l}\text { Able to apply various learning strategies to improve students' thinking and } \\
\text { learning processes in biology. }\end{array}$ & 2.93 & Enough \\
\hline 3 & Knowing about technology that can be used to understand and teach literacy. & 3.10 & Enough \\
\hline 4 & Knowledge of technologies that can be used to understand and teach biology. & 3.07 & Enough \\
\hline 5 & Able to manage and control the class during the learning process. & 3.03 & Enough \\
\hline 6 & Able to use various assessment methods and techniques. & 3.10 & Enough \\
\hline 7 & Knowing the possibility of misconceptions in students. & 3.00 & Enough \\
\hline 8 & Able to direct and guide students to discuss effectively during group work. & 3.00 & Enough \\
\hline 9 & Conducting reflection activities to improve the quality of learning in the classroom. & 3.20 & Enough \\
\hline 10 & Able to adjust teaching styles based on the different abilities of students. & 3.10 & Enough \\
\hline 11 & Having knowledge in developing learning tools. & 3.03 & Enough \\
\hline & Average & 3.06 & Enough \\
\hline
\end{tabular}

The results of the analysis show that the Pedagogical Knowledge (PK) of prospective biology teachers is in sufficient criteria with an average value of 3.06. This shows that the prospective teachers already have 
pedagogical knowledge and are able to apply them in the biology learning that they teach. These include carrying out assessments to students, selecting and implementing learning strategies, being aware of possible misconceptions and learning difficulties in students, managing and mastering the class, as well as doing reflective action.

\section{Pedagogical Content Knowledge (PCK)}

The results of the questionnaire data analysis on the PCK can be seen in Table 8.

Table 8: Results of Pedagogical Content Knowledge (PCK) Analysis

\begin{tabular}{cllcc}
\hline No & & \multicolumn{1}{c}{ Statements } & Mean & Criteria \\
\hline $\mathbf{1}$ & Preparing your own learning scenario. & 3.20 & Enough \\
$\mathbf{2}$ & Able to make lesson plans (RPP) with a good understanding of biology topics. & 3.27 & Enough \\
$\mathbf{3}$ & $\begin{array}{l}\text { Able to choose approaches and learning strategies that are in accordance with } \\
\text { the Biology materials to be taught and the level of development of students. }\end{array}$ & 3.03 & Enough \\
$\mathbf{4}$ & $\begin{array}{l}\text { Able to make difficult biology materials easy for students to understand. } \\
\mathbf{5}\end{array}$ & $\begin{array}{l}\text { Able to develop learning evaluations to measure students' mastery of the biology } \\
\text { materials being taught. }\end{array}$ & 2.03 & Enough \\
& $\quad$ Average & 3.09 & Enough \\
\hline
\end{tabular}

The results of the analysis show that the PCK of prospective biology teachers is in sufficient criteria with an average value of 3.09. This shows that prospective teachers already have the ability to design the learning process by paying attention to appropriate strategies, methods, and learning models according to the characteristics of the materials to be taught.

\section{Technological Content Knowledge (TCK)}

Technological Content Knowledge (TCK) is knowledge on the reciprocal relationship between technology and content or material (Kohler et al., 2014). The results of the questionnaire data analysis on the TCK can be seen in Table 9 .

Table 9: Results of Technological Content Knowledge (TCK) Analysis

\begin{tabular}{clcc}
\hline No & \multicolumn{1}{c}{ Statements } & Mean & Criteria \\
\hline $\mathbf{1}$ & $\begin{array}{l}\text { Able to design independent learning activities for students through the use } \\
\text { of ICT. }\end{array}$ & 3.03 & Enough \\
$\mathbf{2}$ & $\begin{array}{l}\text { Able to choose and use technology that is appropriate to the materials to be } \\
\text { taught. }\end{array}$ & 3.17 & Enough \\
3 & $\begin{array}{l}\text { Using technology to help students understand Biology material. } \\
\text { Average }\end{array}$ & 3.20 & Enough \\
\hline
\end{tabular}

The results of the analysis show that the ability of the prospective biology teachers' Technological Content Knowledge (TCK) is in the sufficient criteria with an average value of 3.13. This shows that prospective teachers have used technology in developing and delivering learning materials that would be taught properly.

\section{Technological Pedagogical Knowledge (TPK)}

Technological Pedagogical Knowledge (TPK) is knowledge on how various technologies can be used in teaching and understanding that using technology can change the way teachers teach (Schmidt and Mishra, 2009). The results of the questionnaire data analysis on the TCK aspect can be seen in Table 10. 
Table 10: Results of Technological Pedagogical Knowledge (TPK) Analysis

\begin{tabular}{|c|c|c|c|}
\hline No & Statements & Mean & Criteria \\
\hline 1 & Using technology to help students understand the materials. & 3.20 & Enough \\
\hline 2 & $\begin{array}{l}\text { Able to facilitate students to use technology to find more information } \\
\text { independently. }\end{array}$ & 3.17 & Enough \\
\hline 3 & $\begin{array}{l}\text { Having knowledge and ability in developing student activities and tasks that } \\
\text { involve the use of technology. }\end{array}$ & 3.03 & Enough \\
\hline 4 & Able to do tests to measure the mastery of the materials online to students. & 3.17 & Enough \\
\hline & Average & 3.14 & Enough \\
\hline
\end{tabular}

The results of the analysis show that the ability of the prospective biology teacher's Technological Pedagogical Knowledge (TPK) is in the sufficient criteria with an average value of 3.14. The results of the open questionnaire analysis show that the prospective teachers use the Quizizz, Kahoot, and Proprofs applications to conduct online learning tests. In addition, prospective biology teachers encourage students to be technologically literate by getting used to using technology in learning such as IT-based learning media, collecting assignments via email, and providing links related to learning materials as a reference for students to study independently.

\section{Technological Pedagogical and Content Knowledge (TPACK)}

Technological Pedagogical and Content Knowledge (TPACK) is a conceptual framework that shows the relationship between three aspects of knowledge that must be mastered by teachers, namely technology, pedagogy, and content. Teachers must integrate technology in learning on certain content. The results of the questionnaire data analysis on the TCK aspect can be seen in Table 11.

Table 11: Results of Technological Pedagogical and Content Knowledge (TPACK) Analysis

\begin{tabular}{|c|c|c|c|}
\hline No & Statements & Mean & Criteria \\
\hline 1 & $\begin{array}{l}\text { Able to use learning media and learning resources that are relevant to } \\
\text { students and the subjects being taught. }\end{array}$ & 3.27 & Enough \\
\hline 2 & $\begin{array}{l}\text { Able to adapt learning strategies and technology with biology material } \\
\text { that will be delivered in classroom learning activities. }\end{array}$ & 3.17 & Enough \\
\hline 3 & $\begin{array}{l}\text { Able to apply different learning strategies and use various computer } \\
\text { applications in the implementation of learning practices. }\end{array}$ & 2.93 & Enough \\
\hline 4 & $\begin{array}{l}\text { Able to integrate appropriate technology, content, and learning } \\
\text { strategies. }\end{array}$ & 3.03 & Enough \\
\hline & Average & 3.10 & Enough \\
\hline
\end{tabular}

The results of the analysis show that the ability of the prospective biology teacher's Technological Pedagogical and Content Knowledge (TPACK) is in the sufficient criteria with an average value of 3.10.

\section{Discussion}

The results of the open questionnaire analysis show that the applications used as communication media include Google Classroom and Zoom Meeting. The use of communication media such as the internet has built a new interaction model in learning in the present time (Yaumi, 2011). Prospective teachers must have IT literacy skills in science learning to find, evaluate, and communicate appropriate information. In addition, they should have the competence to compete in this digital era. As of now, to overcome the problems of practical activities during pandemic, a virtual laboratory has been developed as a learning medium or as an alternative in learning.

The use of virtual laboratories is one of the learning media that is quite effective in terms of place and time with relatively small risks (Kusumaningsih, 2014). Therefore, prospective teachers must have the 
awareness to follow technological developments and understand how to use the technology to support their profession later as a teacher.

The prospective teachers often understand subject matter knowledge separately and in an unorganized manner, resulting in difficulties in accessing that knowledge when teaching (Agustina, 2015). The results of the open questionnaire analysis show that in order to increase knowledge about biology, prospective teachers need to continue to follow the development of biology by reading and seeking information through scientific journals and other learning resources, participating in the use of technology in learning biology, as well as frequently attending seminars on biology. In the condition that a teacher does not have good knowledge of the materials, it can lead to misconceptions and misrepresentation of facts (Koehler and Mishra, 2009).

Prospective teachers must also be able to design practicum activities for learning purposes and be adapted to the materials being studied as practicum activities can support students' understanding of the materials. Biological experiments that have been designed for learning purposes are the manufacturing of herbarium, fermentation in tempe making, how the lungs work, food content testing, practicum on the influence of external factors on plant growth, preservation of animal and plant species, as well as practicum on osmosis and diffusion processes.

The results of the open questionnaire analysis show that prospective teachers assessed students before and after the learning process by using written tests, observation on students' learning activities, and skills assessment performance tests. Students were assessed in terms of knowledge, attitudes, and skills. If there are students who have difficulty understanding the material being taught, they would ask again which material is difficult, then explain, discuss, as well as provide them with learning videos or relate the concept with everyday experiences. In addition, prospective teachers also use peer tutors because usually learning methods which encourage students to share their knowledge with friends will be easier to understand.

In the case there are misconceptions, prospective teachers will straighten the facts, find the causes, and evaluate them so that misconceptions do not occur again by providing a clearer understanding of the materials and showing concrete examples. The way students manage the class while learning takes place is by using interesting learning strategies to keep students listening. These prospective teachers also give apperception at the beginning of the lessons as well as applying methods and models that are appropriate to class conditions. As prospective teachers, they must also be able to develop learning tools that can later be used in the learning process. The learning tools that have been designed include interactive PPT, LKPD, and e-learning based on Google Sites.

Pedagogical Content Knowledge (PCK) is knowledge on the use of pedagogical principles for learning on various characteristics of the materials. This pedagogical principle relates to the selection and use of learning strategies, media methods, and other pedagogical methods based on the characteristics of the materials (Paidi et al., 2021). In the condition that teachers have good PCK skills, they will know what approach is right for the teaching process and how content elements can be arranged for good learning (Suyanto, J. et al., 2020). This shows that prospective biology teachers can understand how to integrate knowledge of technology, pedagogy, and content in the learning process. Chai et al. (2013) state that it is necessary to help prospective teachers to build TPACK knowledge, especially for constructivist-oriented student-centered learning where technology is needed to help improve students' understanding.

\section{Conclusions}

The ability of Technological Pedagogical and Content Knowledge (TPACK) among the prospective teachers at the Biology Education Department A private university in Jakarta, Indonesia is in sufficient criteria with an average value of 3.15. The TPACK ability of prospective teachers still needs to be improved in several aspects including mastery of content, pedagogy, and technology. Moreover, an ICT-based educational innovation is needed that aims to develop learning tools and instruments based on TPACK for prospective teachers of the Biology Education Department A private university in Jakarta, Indonesia. With the development of TPACK-based learning tools, it is hoped that it will make it easier for prospective teachers to teach in the classroom and provide motivation for them to become professional teachers who meet competency standards, namely mastery of technology, science, skills, and attitudes. This research is 
limited to the aspects of TPACK knowledge of prospective biology teachers and has not analyzed the application of TPACK in the learning process by prospective teachers. It is necessary to conduct further evaluation of the TPACK ability of prospective teachers to use tests as research instruments. In addition, it is also necessary to study further on the application of TPACK in the learning process for various students in other departments.

\section{ACKNOWLEDGMENT}

The author would like to thank Lemlit UHAMKA for funding this research

\section{REFERENCES}

Agustina, P. (2015). Pengembangan PCK (pedagogical content knowledge) mahasiswa calon guru biologi fkip universitas muhammadiyah surakarta melalui simulasi pembelajaran. Jurnal Penelitian dan Pembelajaran IPA, 1(1),1-15.

Bhakta, K \& Dutta, N. (2016). Impact of information technology on teaching-learning process. International Research Journal of Interdisciplinary and Multidisciplinary Studies, 2 (11), 131-138.

Chai, C. S., Tsai, C. C., \& Koh, J. H. L. (2016). A review of technological pedagogical content knowledge. Educational Technology and Society, 16 (2), 31-51.

Elvianasti. M., Amirullah, G. \& Pramudiani, P. (2019). Profil kemampuan mengajar calon guru biologi pada mata kuliah pembinaan kompetensi mengajar. Jurnal Pembelajaran Biologi. Kajian Biologi dan Pembelajaran, 6 (2),11-23.

Jimoyiannis, A. (2010). Developing a technological pedagogical content knowledge framework for science education: Implications of a teacher trainers' preparation program. Proceedings of Information Science and IT Education Conference (InSITE). 597-607.

Husein, U. (2011). Metode Penelitian untuk skripsi dan tesis bisnis. Jakarta: PT. Raja Grafindo Persada.

Irdalisa (2019). Pengembangan model inkuiri terbimbing berbantuan ict untuk meningkatkan kemampuan technological pedagogical and content knowledge (TPACK), kps, curiosity mahasiswa jurusan pendidikan biologi universitas syiah kuala. [Disertasi, Universitas Negeri yogyakarta].

Irdalisa, Paidi \& Djukri (2020). Implementation of technology-based guided inquiry to improve tpack among prospective biology teachers. International Journal of Instruction,13 (2),33-44.

Irmita, L \& Atun, S. (2018). The influence of technological pedagogical and content knowledge (tpack) approach on science literacy and social skills. Journal of Turkish Science Education, 15 (3), 27-40.

Koehler, M. J., Mishra, P., Kristen, K., Tae, S. S. \& Charles, R. G. (2014). The technological pedagogical content knowledge framework. Newyork: Springer Science Business Media.

Koehler, M. J. \& Mishra, P. (2009). What is technological pedagogical content knowledge? Contemporary Issues in Technology and Teacher Education, 9 (1), 60-70.

Kriek, J. \& Coetzee, A. (2016). Development of a technology integrated intervention in tertiary education. Journal of Baltic Science Education, 15 (6),712-724.

Mario, H., Tobias, P. \& Boris, O. (2016). Desain principles for industrie 4.0 scenarios. Proceedings of the Annual Hawaii International Conference on System Sciences.

Meenakshi (2013). Importance of ict in education. Journal of Research and Method in Education, 1 (4), 232073788.

Mishra, P. \& Koehler, M. J. (2006). Technological pedagogical content knowledge: A framework for integrating technology in teacher knowledge. Teachers College Reord. 108 (6),1017-1054.

Mulyasa. (2009). Standar kompetensi dan sertifikasi guru . Bandung: PT Remaja Rosdakarya

Paidi, Bambang, S., \& Luisa, D. H. (2021). The mastery of technological, pedagogical, and content knowledge among indonesian biology teachers. European Journal of Educational Research, 10 (3), 1063-1073. 
Raja, R. \& Nagasubramani, P. C. (2018). Impact of modern technology in education. Journal of Applied and Advanced Research. 3 (1), 33-35.

Rahmadi, F. (2015). Pengembangan perangkat pembelajaran berbasis pemecahan masalah berorientasi pada kemampuan penalaran dan komunikasi matematika. Jurnal Pendidikan Matematika, 10 (2), 137-145.

Sani, R.A. (2013). Inovasi pembelajaran. Jakarta: Bumi Aksara.

Schmidt, D. A., Baran, E., Thompson, A. D., Mishra, P., Koehler, M. J., \& Shin, T. S. (2009). Technological pedagogical content knowledge (TPACK): The development and validation of an assessment instrument for pre-service teachers. Journal of Research on Technology in Education. 42(2),123-149.

Suyanto, J., Masykuri, M. \& Sarwanto (2020). Analisis kemampuan technolgical, pedagogical, and content, knowledge guru biologi SMA dalam menyusun perangkat pembelajaran materi sistem peredaran darah. Inkuir: Jurnal Pendidikan IPA. 9 (1), 46-57.

Yaumi, M. (2011). Integrasi teknologi informasi dan komunikasi dalam pembelajaran. Lentera Pendidikan. 6 (108), 1017-1054. 